\title{
Geographic Characteristics of Soya Production in Agricultural Areas of Vojvodina Region
}

\section{Igor Stamenković', Danica Bošnjak², Aleksandra Stamenković ${ }^{3}$}

\begin{abstract}
By its quality and energy value, soya exceeds most of agricultural products and not only those concerned with husbandry. For almost three centuries, its growing has a rising tendency observed both through the aspect of sowing areas and aspect of yield, which inevitably leads to the growth of production scope. The application of selection methods has contributed to the significant growth of protein content in the seed, which additionally contributed to the permanent trend of soya production growth in the world. The data about the areas, yields and production of soya per production areas were gathered first in different municipalities, which were later classified into production areas which demanded the use of statistical methods: average values and base indexes. The result of the research showed that there is certain accordance when studying the yields on areas determined by natural factors and those determined by the level of average crop yield. What has also been noticed is the need of a further study of regionalization problems, which would only help prove future justification and determine the development of the arrangement of agricultural production in Vojvodina.
\end{abstract}

Key words: soya, geographical characteristics, production areas, agriculture/ husbandry, Vojvodina

\footnotetext{
assistant, Department of Geography, Tourism and Hotel Industry, Faculty of Natural Sciences and Mathematics, Novi Sad, igorrogi@neobee.net

2 Department of Agricultural Economics and Rural Sociology, Faculty of Agriculture, Novi Sad, danicab@polj. ns.ac.yu

3 BSC in agriculture - agroeconomy, Novi
} Sad, igorrrogi@yahoo.com

\section{Introduction}

The earliest written European sources on food made of soya bean date back to 1597 when Florence inhabitant Francesco Carletti visited Nagasaki. Moreover, food made of soya came to Europe earlier than soya bean itself. The Dutch, as requested by Louis XIV, started importing Japanese soya sauce to France in 1670 which was used as a food spice during baroque banquets at the court. Soya is one of the basic agricultural crops from the group of industrial-oil plants. It has important nutritive characteristics and as such is considered a significant raw material in food industry. Apart from the fact that it is used in human and animal nutrition, it also represents a labour form. Unfortunately, when soya production is concerned, except the common appearance of economic inefficiency due to agrarian measures, what is also present are certain biological constrictions which disable its more massive presence. Namely, this agrarian culture implies the growth on quality soils and does not bear being varied in a crop rotation more than $17 \%$.

\section{Origin, distribution and economic importance of soya}

Great economic importance of soya lies in the chemical composition of its bean which has a high content of proteins (24-55 $\%)$, oils (17-24\%) and non-nitric extractive substances. Soya proteins, according to their amino acid content and digestibility, are very similar to the proteins of animal origin. Its oil is semi-dry, edible, of good quality and is used for further processing. Soya flour is used when making bread for diabetics and is added to wheat flour in order to enrich bread with proteins. Moreover, it is used in oil industry; first class table oil is made of refined oil. In dairy industry it is used for the production of cheese (Chinese, tofu), yoghurt, butter, sour cream and kefir. The seed is rich in vitamins $B_{1}$, $\mathrm{B}_{2}, \mathrm{C}, \mathrm{D}, \mathrm{E}, \mathrm{K}$ and provitamin $\mathrm{A}$, whereas in its technological maturity it is used as a raw material in can industry. Proteins are used for the production of plastic mass- es, linoleum, tires, fibers, water resistant glues. Besides that, soya oil is used in pharmacy when making stearin, soaps, glycerin, different creams and is as well used as a component of oil and printing colours and high quality sprays used in automobile and airplane industry, when making medicines and in confection, textile and other industries (Đorđević, Nenadić, 1980). Furthermore, soya has a great agrotechnical importance since it enriches the soil with nitrogen (100/200 $\mathrm{kg} / \mathrm{ha})$, which equals $500-1000 \mathrm{~kg} / \mathrm{ha}$ of mineral nitric fertilizer. It leaves the soil in a rather favourable physical condition, and as such it represents a good component in crop rotation (Todorović, Kondić 1993). There are two section plants for soya processing on the territory of Serbia, one in Obrenovac and the other one in Bečej. Each day the science and economy acquire new knowledge of the possible usage of this magic plant. Soya has a great economic importance as it has a high place when areas, yields and international sales are concerned.

Soya belongs to some of the oldest plants on the Earth and it originates from Asia (China-Manguria) where it was grown in the areas between $20^{\circ}$ and $45^{\circ}$ north latitude in 2.700 BC (Đorđević, Nenadić, 1980). It is thought to have originated from wild soya bean Glycine usuriensis. From China it spread to Eastern and Southeastern Asia (Korea, Japan, Vietnam, Indonesia and India). It started being grown as a field crop in Europe in the $19^{\text {th }}$ century. According to Shurtleff and Aoyaga (2004) it was taken to America in 1804 . It came to our country at the beginning of last century. It started to be grown more intensely just before World War II. The optimal areas of its growth are between the equator and $56^{\circ}$ north latitude and the equator and $45^{\circ}$ south latitude. Today soya is grown in two major production areas; the first one is.China, Korea, Indonesia and Japan, whereas the second one is: the USA, Canada, Brazil and Argentina. It covers and area of 13 million ha in the first production area and about 11 million ha in the second one. The greatest yields are achieved in the USA: Ohio, Indiana, Illinois, Iowa and Missouri (Tomić, et 
al. 1999). Some recent researches (Bošnjak, Rodić, 2006) indicate that soya is today grown on the area somewhat larger than 90 million hectares and the total production capacity is 204 million tones with an average yield of $2.2 \mathrm{t}$ bean/ha. The areas under soya in Europe cover only $1.5 \%$ of world areas under this crop. They produce averagely $1.9 \mathrm{t} / \mathrm{ha}$, which makes an average production of approximately 2.1 million tones of bean. In the former Serbia and Montenegro soya was grown on an average area of about 100.000 ha (only $0.11 \%$ of world areas or $7.2 \%$ of areas in Europe under this crop) mainly in Vojvodina (about $92 \%$ of all areas under this crop in Serbia and Montenegro).

\section{Characteristics and determination of agricultural production areas of Vojvodina}

Agricultural production areas in Vojvodina are observed through different climatic and edaphic conditions. The specific conditions led to different locations and distribution of certain production areas on the territory of Vojvodina, which is shown on map 1. The area of Vojvodina in the period 2003-2005 handles the fund of 1.570 .584 ha of ploughed fields. The overall capacities of ploughed fields are used by agricultural companies and agricultural households. The dominant usage of ploughed areas belongs to agricultural households (69.96\%), whereas the agricultural companies manage the fund of $30.04 \%$ of all ploughed areas in Vojvodina (Rošulj, 2006).

It is possible to conduct the division of Vojvodina into certain production areas by using two methods. The first one is based upon the climatic conditions, geological and pedological characteristics, vegetation surface cover and agro-ecological conditions of soil and its natural boundaries. The second method is based upon administrative municipality area and as its classification parameter the achieved average yield of basic agricultural crops is used. By the comparative analysis of areas it can be concluded that these methods are complementary although they observe the same research object from different viewpoints. At the same time, it is necessary to point out the fact that a large number of areas (about 820.000 ha) in Vojvodina are affected by soil and surface waters, and that is why it is necessary to apply melioration which would lead to the more intense cultivation of soil (Jan, 2004). The whole territory for agricultural production of Vojvodina is divided according to plant and crop regionalization into four areas. The first area comprises the western parts with soils and floodable areas of the Danube and the Sava, as well as the southeastern part with the higher precipitation level. The second area includes the central part with an average precipitation level and with chernozem loess plains. The third area includes the eastern part with the least precipitation, which is characterized by marshy dark, fertile soil (loess soils of Banat). The last area includes Subotica and Deliblat sandy terrain (Stojković, 1949). Apart from forest exploitation of soil there is also thge agricultural exploitation where we can identify agricultural/husbandry, orchard-wine growing and meadow-pasture exploitation. Each of these exploitation types is performed on several different localities that have somewhat changed climaticedaphic and relief conditions, which actually makes the basis for their division into several parts being separate areas with the same type of soil exploitation.

\section{The first method used when determining an area according to natural factors}

According to the natural factors, the following agricultural areas are identified on the territory of Vojvodina (Stojković, 1972):

A. Forest production: 1. areas of high forests (high forests of Fruška Gora mountain and high forests of Vršac mountains); 2. areas of low forests (climatic-hydrologically conditioned low forests, hydrologically conditioned low forests and edaphically conditioned low forests).

B. Agricultural production: 3. areas of orchard-wine growing production (areas of orchard-wine growing production of Fruška Gora mountain, Vršac mountains, Subotica-Horgos sandy terrain, Deliblat sandy terrain and plain areas); 4. areas of agricultural production (Western Bačka, Northern Bačka, Southern Bačka, Northern Banat, Middle Banat, Southern Banat, Eastern Banat, Northern Srem, Eastern Srem and Southern Srem); 5. areas of specific production (the ones which are territorially identified but are scattered over smaller or bigger areas in the shape of islands or oases; e.g. areas of vegetable cultures, subtropical cultures of rice and cotton, areas under hemp, industrial pepper, broomcorn, hops, areas used for the production of seed, flowers, meadows and pastures on marshy terrains, areas used for hunting and fishing).

The areas of agricultural production have the characteristics:

BAČKA: I area of Western Bačka - in cludes The Danube Basin from Bezdan to Futog and leans towards the Danube. The deciduous forests as well as marshy vegetation are recognizable near the banks. This vegetation turns into steppe-grassy vegetation form on higher levels. The vegetable production is developed on alluvial soils (Kupusina, Futog)and hemp production on meadow fertile soils (Vajska, Bačka Palanka, Bački Petrovac and others); II area of Northern Bačka - includes the state border with Hungary, the road Gakovo-Sombor to the Danube- Tisa-Danube canal, its south border being the brim of Telečka all the way to Vrbas and then a subtle arch towards Bačko Petrovo Selo; the Tisa river makes its eastern border. The lack of precipitation can be compensated by agrotechnical measures. The basic soil here is carbonated chernozem with meadow fertile soil. The soils of the Tisa Basin are suitable for the production of root-like vegetables (Ada, Mol, Bačko Petrovo Selo), as well as for the production of indusrial pepper (Horgoš and Martonoš); III area of Southern Bačka - includes the southern part of Bačka. The production capacity of this area distinguishes itself from other areas due to fertile meadow soil and chernozem that cover about half of the total area. This is the oasis for vegetable production (Futog, Kać, Vilovo, Đurđevo and others).

BANAT: IV Area of Northern Banat - it belongs to steppe zone and the area production is lower than in the other areas. The most common soils are those of hard, mechanical composition. Forests of willow and poplar can be found near the banks of the Tisa. A special problem is a more intense usage of marshy terrains; $\mathrm{V}$ area of Middle Banat - with its greater part it belongs to the biotope of loess high terrain, and with its smaller part to loess plateau on Botoš-Orlovat route. The carbonated chernozem and meadow fertile soil are the part of the most fertile soil. The limiting factors are hydrogen soils, marshy fertile soils, etc, whose exploitation requests meliorative measures; VI Area of Southern Banat - is southwestern part of Banat (Deliblat sandy terrain). The heterogeneous edaphic conditions are present, which has brought about the emergence of different biotopes (loess high terrain, loess plateau and sandy soil). This is an excellent area for orchard-wine growing production, sugar beet production, vegetable production (Pančevo marsh and Glogonj-Sefkerin-Opovo route), and the production of husbandry crops on the sand: rye, potato, red pepper, vetch; VII Area of Eastern Banat - includes the area between Vršac mountains, with all the slopes and plains, whereas in the west it comprisws Deliblat sandy terrain and southern Banat plateau. The major part of agricultural areas stretches along Uljma-Vršac-Veliko Središte all the way to the north. This area is characterised by a large amount 
of precipitation (over $600 \mathrm{~mm}$ ), higher temperatures and marshy fertile soil. Cotton is successfully grown (Ritiševo), as well as rice, hay and lucerne seed on slightly alkali soils whereas red clover is grown on acid soils.

SREM: VIII Area of Northern Srem - considering its size it is the smallest agricultural area in Vojvodina. The production capacity of Fruška Gora mountain is rather high on chernozem soil. The smaller areas under crops are to be found on the carbonated chernozem and meadow fertile soils; IX Area of Eastern Srem - considering its productivity, the significant presence of chernozem soil, great precipitation and favourable thermic conditions, it belongs to highly productive areas; $\mathrm{X}$ area of Southern Srem - it covers the territory of Srem the Sava Basin from Bežanija in the east up to the border of Slavonija in the west. The geological base on higher levels consists of loess soil, whereas along the Sava river there is an area of alluvial deposits. Similar to this area is the area of Eastern Banat, whose characteristic is also the lack of carbonated chernozem and meadow fertile soils. The types of soils that prevail there are marshy fertile soil, pseudogley, marshygley clay soil and marshy terrain.

The influence of the natural factors of production is conditioned by the production intensity, the higher the influence the lower the intensity level. . As the production intensity grows, the importance of natural factors falls whereas the importance of other factors such as anthropogenic conditions rises.

\section{The second method used when determining an area according to the economic results of agricultural production}

The basic standpoint here is municipality localities considered in a form of microregions, all with a tendency to grouping production areas systematically according to specific characteristics, taking econometric method as a model. When agricultural crops are concerned, what needs to be determined in a certain period is average yield per years, per ownership sectors (state, individual) and per municipalities (localities). That is how the interaction quantification of the determined mean values observed as independent variables is performed. The classification of yields of the observed crops is as well performed by applying the means of so-called l-distance, method by B. Ivanović (1963). This method requires two categories: the classification of crops according to the intensity in production and their importance according to their presence in cultivated lands. What else is observed is the mutual interdepend- ence of the obtained yields as the correlation of obtained yields per area unit in different microregions and as the correlation of municipality level according to the level of obtained yield. By comparing the obtained results it can be noticed that the values of correlation coefficients are rather the same to a great extent. The classification of municipalities performed on the basis of the obtained yields of certain husbandry crops is different so that the possibilityof reliable grouping of municipalities according to the level of yields is limited. The next phase is the division of Vojvodina into certain subregions, individual homogeneous areas by means of the application of two indexes: yield of wheat units (dt/ha) per land unit and number of cattle heads per 100 ha of agricultural area. Thus, from the aspect of the production development level there are four subregions identified. Two of them, number I and IV are further divided into I1, I 2 and IV 1 and IV 2 to reduce the possible variation (Jan, 2004). By skipping the process of data processing by this method, we will emphasize the fact that the present production conditions are not used in Vojvodina in the most adequate way. The share of certain crops in sowing structure is more determined by tradition and habits than by realistic economic importance. The most common problem is that the areas with the highest density of agricultural population (agrarian density) have the lowest level of production intensity.

\section{Comparative Study of Methods for Determining Production Areas}

It is of great importance to conclude that there is a strong parallel when researching yields in the areas determined by natural factors and those determined by the amount of average crops yield on them. Although the methods in their research start from different viewpoints, what is obvious is their compatibility shown in the obtained parallel research results. Any deviations from the complete accordance point to the need of further study of the regionalization problem, which actually demands the use of long-term data series. The aim and result of such a research would be proving the future justification and establishing the course of development when arranging agricultural production in Vojvodina.

\section{Research Results}

In the period 1976-1995 the total sum of soya production (table 1) presented in tones was significantly lower on agricultural households than in the agricultural companies. When Vojvodina is concerned, the greatest production in 1970s was achieved in 1979, whereas in 1980 os the significant growth of soya production was recorded in the peri- od 1982-1984 when it reached $160.000 \mathrm{t}$. After 1991, the production decreased and then in 1995 it stared growing again. In 2000, Southern Bačka had about 120 times higher production than Northern Srem, which at the same time represents the maximum in the last twenty years. Moreover, South ern Bačka achieved in 2002 the highest soya production $(46.60 \%$ ) in Vojvodina in the last six years. The second place belongs to Western Bačka and Southern Srem (period 2000-2002.). Northern and Eastern Srem recorded the lowest production in the same period (averagely only $1 \%$ ).

Ploughed agricultural areas in Vojvodi$n \boldsymbol{a}$ - The greatest number of ploughed fields in Vojvodina is to be found on the area of Southern Bačka (the first place belongs to the municipality of Novi Sad), whereas the smallest number is registered in Northern Srem (Beočin municipality). The relative participation of certain agricultural areas presented in the form of ploughed fields ranges between $1.23 \%$ (Northern Srem) to 17.29 \% (Southern Bačka). It is important to mention that the agricultural area of Bačka participates in the overall number of ploughed fields in Vojvodina with $44.94 \%$, whereas only $15.31 \%$ belongs to the agricultural area of Srem. The agricultural companies are the owners of about 472.000 ha of the ploughed fields. Moreover, the agricultural companies from Bačka own the greatest number of ploughed capacities (Southern Bačka). The analysis shows that the production area of Northern Srem owns the smallest number of those capacities. The agricultural households manage 1.098 .850 ha of ploughed areas (about $70 \%$ of all ploughed capacities in Vojvodina). By ranking them by the size of ploughed areas, it can be concluded that agricultural households from the areas of Southern Bačka, Northern Bačka and Southern Banat take the first place. Again, the smallest number of the ploughed fields belongs to the households of Nothern Srem. On the whole, the husbandry production areas have different production potential presented through available ploughed area.

Industrial crops in observed regions of Vojvodina - In the period observed (2003-2005), on the territory of Vojvodina, the average areas under industrial crops were 373.302 ha. The agricultural companies organize their production on 165.841 ha $(44.43 \%$ of all areas under this crop in Vojvodina), while agricultural households grow industrial crops on the average area of 207.461 ha $(56.57 \%)$. The data in table 2. indicate that the area of Southern Bačka has the biggest average areas under industrial crops (70.189 ha or about $19 \%$ of areas under industrial crops in Vojvodina). The regions of Western Bačka, Middle Banat and Southern Banat take the second place. The smallest areas under industrial crops 
are registered in Northern Srem (Beočin municipality). The relative participation of certain production areas in all areas under industrial crops ranges between o.61 \% ( Northern Srem) to 18.80 \% (Southern Bačka). It must certainly be emphasized that the production areas of Bačka participate in all areas under industrial crops in Vojvodina with $44.34 \%$, production areas of Banat with $42.53 \%$, and production areas of Srem with $13.14 \%$. The analysis of areas under industrial crops in the agricultural companies indicates that the areas under this crop range between 490 ha to 32.154 ha. In the production areas from the region of Bačka, the industrial crops are grown on somewhat less than $50 \%$ of all areas. What marks the difference between the agricultural companies and households is the fact that the agricultural households have larger areas under industrial crops.

Harvested areas of soya in certain production areas - In the period 2003-2005 soya in Vojvodina was grown on an average area of 120.779 ha. Based on the data from table 3. it can be concluded that all the subjects have the same participation in harvested areas. The average harvested areas vary between 693 ha (Northern Srem) and 37.402 ha (Southern Bačka). The analysis shows that $70 \%$ of areas under soya are concentrated in three regions: Southern and Western Bačka, Southern Srem. The remaining $30 \%$ of areas are divided among seven regions and when the individual participation of regions in total areas is less than $10 \%$. Widely speaking, it is noticed that the region of Bačka takes the dominant place (60.79\%). The agricultural companies grow soya on an average area of 60.404 ha. The greatest part of these areas is on the territory of Southern Bačka (14.384 ha), while the Western Bačka covers somewhat smaller areas (13.591 ha). When the agricultural households are concerned, it is noticed that the dominant place be-

Table 1 Soya production in Vojvodina for the period 1976-1995.

\begin{tabular}{|c|c|c|c|c|c|c|}
\hline \multirow[b]{2}{*}{ Year } & \multicolumn{2}{|c|}{$\begin{array}{l}\text { Agricultural } \\
\text { companies }\end{array}$} & \multicolumn{2}{|c|}{$\begin{array}{l}\text { Agricultural } \\
\text { households }\end{array}$} & \multicolumn{2}{|c|}{$\begin{array}{l}\text { Total } \\
\text { sum }\end{array}$} \\
\hline & $\begin{array}{l}\text { Average } \\
\text { income } \\
\text { (kg/ha) }\end{array}$ & $\begin{array}{c}\text { Total sum } \\
\text { production } \\
\text { (t) }\end{array}$ & $\begin{array}{l}\text { Average } \\
\text { income } \\
\text { (kg/ha) }\end{array}$ & $\begin{array}{c}\text { Total sum } \\
\text { production } \\
\text { (t) }\end{array}$ & $\begin{array}{l}\text { Average } \\
\text { income } \\
(\mathrm{kg} / \mathrm{ha})\end{array}$ & $\begin{array}{c}\text { Total sum } \\
\text { production } \\
\text { (t) }\end{array}$ \\
\hline 1976 & 1.63 & 31.938 & 1.46 & 3.942 & 1.55 & 35.88 \\
\hline 1977 & 2.17 & 46.2 & 2.14 & 4.327 & 2.16 & 50.527 \\
\hline 1978 & 1.95 & 46.721 & 1.95 & 3.881 & 1.95 & 50.602 \\
\hline 1979 & 2.23 & 51.084 & 2.34 & 3.28 & 2.29 & 54.364 \\
\hline 1980 & 2.09 & 26.766 & 1.8 & 1.436 & 1.95 & 28.202 \\
\hline 1981 & 2.04 & 71.978 & 1.95 & 5.859 & 2 & 77.837 \\
\hline 1982 & 2.69 & 151.632 & 2.45 & 16.969 & 2.57 & 168.601 \\
\hline 1983 & 1.97 & 135.163 & 1.81 & 25.144 & 1.89 & 160.307 \\
\hline 1984 & 2.01 & 143.56 & 1.82 & 20.446 & 1.92 & 164.006 \\
\hline 1985 & 1.69 & 103.972 & 1.53 & 12.2 & 1.61 & 116.172 \\
\hline 1986 & 2.36 & 122.179 & 2.3 & 22.661 & 2.33 & 144.84 \\
\hline 1987 & 2.35 & 121.201 & 2.27 & 27.279 & 2.31 & 148.48 \\
\hline 1988 & 1.62 & 87.232 & 1.54 & 20.945 & 1.58 & 108.177 \\
\hline 1989 & 2.3 & 99.751 & 2.24 & 15.297 & 2.27 & 115.048 \\
\hline 1990 & 1.51 & 65.529 & 1.62 & 12.569 & 1.57 & 78.098 \\
\hline 1991 & 2.71 & 93.159 & 2.53 & 9.873 & 2.62 & 103.032 \\
\hline 1992 & 1.33 & 59.185 & 1.25 & 17.736 & 1.29 & 76.921 \\
\hline 1993 & 1.35 & 50.123 & 1.47 & 17.988 & 1.41 & 68.111 \\
\hline 1994 & 1.69 & 58.3 & 1.58 & 14.674 & 1.64 & 72.974 \\
\hline 1995 & 2.09 & 76.17 & 2.05 & 19.575 & 2.07 & 95.745 \\
\hline Sum: & - & 1641.843 & - & 276.081 & - & 1917.924 \\
\hline Average & 1.99 & - & 1.91 & - & 1.95 & - \\
\hline
\end{tabular}

longs to the regions of Southern and Western Bačka, and Southern Srem. About $83 \%$ of all areas under soya are concentrated in these regions, while the remaining $17 \%$ are to be found in the other ones.

Presence of soya in ploughed areas The more realistic picture of the place soya takes in certain husbandry production areas in Vojvodina can be obtained when the relationship between harvested areas under soya and available ploughed capacities is observed. In the observed three-year period, soya occupies $7.69 \%$ of ploughed areas in Vojvodina. The agricultural companies use about $13 \%$ of their ploughed fields, whereas agricultural households use $5.49 \%$ of those fields. The earlier researches performed by Reljin et al. (1997) show that the

Table 2 Average areas (ha) under industrial crops in Vojvodina for the period 2003-2004.

\begin{tabular}{|l|r|r|r|r|r|r|r|r|r|}
\hline \multirow{2}{*}{ Production area } & \multicolumn{3}{|c|}{ Total sum } & \multicolumn{3}{c|}{ Agricultural companies } & \multicolumn{3}{c|}{ Agricultural households } \\
\cline { 2 - 12 } & Average & \% part & Rang & Average & \% part & Rang & \multicolumn{1}{c|}{ Average } & \% part & \multicolumn{1}{c|}{ Rang } \\
\hline Western Bačka & 55.804 & 14,95 & 2 & 27.716 & 16,71 & 2 & 28.089 & 13,54 & 2 \\
\hline Northern Bačka & 39.52 & 10,59 & 5 & 18.762 & 11,31 & 4 & 20.758 & 10,01 & 6 \\
\hline Southern Bačka & 70.189 & 18,80 & 1 & 32.154 & 19,39 & 1 & 38.035 & 18,33 & 1 \\
\hline Northern Banat & 36.132 & 9,68 & 7 & 16.18 & 9,76 & 6 & 19.953 & 9,62 & 7 \\
\hline Middle Banat & 48.442 & 12,98 & 3 & 23.078 & 13,92 & 3 & 25.365 & 12,23 & 4 \\
\hline Southern Banat & 42.899 & 11,49 & 4 & 17.036 & 10,27 & 5 & 25.864 & 12,47 & 3 \\
\hline Eastern Banat & 31.295 & 8,38 & 8 & 12.412 & 7,48 & 8 & 18.883 & 9,10 & 8 \\
\hline Northern Srem & 2.274 & 0,61 & 10 & 490 & 0,30 & 10 & 1.784 & 0,86 & 10 \\
\hline Eastern Srem & 9.882 & 2,65 & 9 & 4.756 & 2,87 & 9 & 5.126 & 2,47 & 9 \\
\hline Southern Srem & 36.867 & 9,88 & 6 & 13.26 & 8,00 & 7 & 23.607 & 11,38 & $\mathbf{1 0}$ \\
\hline vOJVODINA & $\mathbf{3 7 3 . 3 0 2}$ & $\mathbf{1 0 0}$ & & $\mathbf{1 6 5 . 8 4 1}$ & $\mathbf{1 0 0}$ & & $\mathbf{2 0 7 . 4 6 1}$ & $\mathbf{1 0 0}$ & \\
\hline
\end{tabular}

Source: Internal documentation of the Provincial Bureau of Statistics in Novi Sad for the period 2003-2004 
Table 3 Average harvested areas of soya (ha) in production areas in Vojvodina for the period 2003-2005.

\begin{tabular}{|c|c|c|c|c|c|c|c|c|c|}
\hline \multirow[b]{2}{*}{ Production area } & \multicolumn{3}{|l|}{ Total sum } & \multicolumn{3}{|c|}{ Agricultural companies } & \multicolumn{3}{|c|}{ AGRICULTURAL HOUSEHOLDS } \\
\hline & $\begin{array}{l}\text { Average } \\
\text { area (ha) }\end{array}$ & $\begin{array}{l}\% \\
\text { participation }\end{array}$ & Rang & $\begin{array}{l}\text { Average } \\
\text { area (ha) }\end{array}$ & $\begin{array}{l}\% \\
\text { participation }\end{array}$ & Rang & $\begin{array}{l}\text { Average } \\
\text { area (ha) }\end{array}$ & $\begin{array}{l}\% \\
\text { participation }\end{array}$ & Rang \\
\hline Western Bačka & 30.627 & 25,36 & 2 & 13.591 & 22,50 & 2 & 17.036 & 28,22 & 2 \\
\hline Northern Bačka & 5.382 & 4,46 & 7 & 4.361 & 7,22 & 7 & 1.021 & 1,69 & 7 \\
\hline Southern Bačka & 37.402 & 30,97 & 1 & 14.384 & 23,81 & 1 & 23.018 & 38,13 & 1 \\
\hline Northern Banat & 3.028 & 2,51 & 8 & 2.357 & 3,90 & 8 & 671 & 1,11 & 9 \\
\hline Middle Banat & 8.442 & 6,99 & 5 & 6.654 & 11,02 & 3 & 1.788 & 2,96 & 6 \\
\hline Southern Banat & 8.619 & 7,14 & 4 & 6.48 & 10,73 & 5 & 2.139 & 3,54 & 5 \\
\hline Eastern Banat & 7.859 & 6,51 & 6 & 4.415 & 7,31 & 6 & 3.444 & 5,70 & 4 \\
\hline Northern Srem & 693 & 0,57 & 10 & 54 & 0,09 & 10 & 640 & 1,06 & 10 \\
\hline Eastern Srem & 2.259 & 1,87 & 9 & 1.545 & 2,56 & 9 & 714 & 1,18 & 8 \\
\hline Southern Srem & 16.467 & 13,63 & 3 & 6.563 & 10,86 & 4 & 9.904 & 16,40 & 3 \\
\hline VOJVODINA & 120.779 & 100 & & 60.404 & 100 & & 60.375 & 100 & \\
\hline
\end{tabular}

Source: Internal documentation of the Provincial Bureau of Statistics in Novi Sad for the period 2003-2005

presence of soya in ploughed areas of Vojvodina was only $3.38 \%$ in the period 1986 1995. What is noticed in the last couple of years is a rapid growth of this crop on agricultural households, which also conditioned the the growth of the presence of this crop in the ploughed areas. The greatest presence of soya in the ploughed areas is to be found in Western Bačka, whereas the smallest one is in Northern Banat and Northern Bačka. Moreover, when only the region of Bačka is observed, it is noticeable that the northern part has smaller presence of soya in ploughed areas than other parts. Banat and Srem do not experience such differences. The agricultural companies plant soya on a significant part of their ploughed areas; the biggest areas to be found in Eastern Banat and then in Southern Srem and Western Bačka. The regions with the smallest presence of soya in ploughed areas are Northern Srem and Northern Banat. The agricultural compa- nies from the area of Bačka use about 14 $\%$ of their ploughed fields for soya production; Banat uses $11 \%$ and Srem a bit over $15 \%$. The observed relative participation among agricultural households is the largest on the territory of Western (12.97\%) and Southern Bačka (12.52\%), while the smallest one is on the territory of Northern Bačka (0.65\%) and Northern Banat (0.73\%). Compared with the average of the agricultural households in Vojvodina (5.49\%), a greater participation of areas under soya in ploughed fields belongs to the households from the regions of: Eastern Bačka, Southern Bačka and Southern Srem. At the same time, when we compare the presence of areas under soya in the ploughed fields of the agricultural companies to those of agricultural households, it is noticed that Eastern and Southern Banat have much more significant presence of soya in the agricultural companies than in the agricultural households. These differences indicate that the agricultural households in certain regions use a small part of their ploughed areas for soya planting although there are favourable natural conditions for that.

Presence of soya in areas under industrial crops - Starting form the fact that soya belongs to the group of industrial crops, it is rather important to observe its place in that specific group. When we look at this correlation in Vojvodina (table 4) it can be seen that the areas under soya make a bit less than $1 / 3$ of areas under all industrial crops, which means that it actually represents a every important industrial plant The greatest presence of soya among the industrial crops is in Western and Southern Bačka, while the smallest one is in Northern Banat and Northern Bačka. Banat takes the last place in Vojvodina concerning the presence of soya among the industrial crops. What else needs to be mentioned is the region of Southern Srem where soya represents the leading indus-

Table 4 Average areas (ha) under soya and industrial crops in the period 2003-2005.

\begin{tabular}{|c|c|c|c|c|c|c|}
\hline \multirow[b]{2}{*}{$\begin{array}{l}\text { Production } \\
\text { area }\end{array}$} & \multicolumn{2}{|c|}{ Total sum } & \multicolumn{2}{|c|}{ Agricultural companies } & \multicolumn{2}{|c|}{ Agricultural households } \\
\hline & $\begin{array}{c}\text { Average area } \\
\text { under soya (ha) }\end{array}$ & $\begin{array}{c}\text { Average area } \\
\text { under industrial } \\
\text { crops (ha) }\end{array}$ & $\begin{array}{c}\text { Average area } \\
\text { under soya (ha) }\end{array}$ & $\begin{array}{c}\text { Average area } \\
\text { under industrial } \\
\text { crops (ha) }\end{array}$ & $\begin{array}{c}\text { Average area } \\
\text { under soya (ha) }\end{array}$ & $\begin{array}{c}\text { Average area } \\
\text { under industrial } \\
\text { crops (ha) }\end{array}$ \\
\hline Western Bačka & 30.627 & 55.804 & 13.591 & 27.716 & 17.036 & 28.089 \\
\hline Northern Bačka & 5.382 & 39.52 & 4.361 & 18.762 & 1.021 & 20.758 \\
\hline Southern Bačka & 37.402 & 70.189 & 14.384 & 32.154 & 23.018 & 38.035 \\
\hline Northern Banat & 3.028 & 36.132 & 2.357 & 16.18 & 671 & 19.953 \\
\hline Middle Banat & 8.442 & 48.442 & 6.654 & 23.078 & 1.788 & 25.365 \\
\hline Southern Banat & 8.619 & 42.899 & 6.48 & 17.036 & 2.139 & 25.864 \\
\hline Eastern Banat & 7.859 & 31.295 & 4.415 & 12.412 & 3.444 & 18.883 \\
\hline Northern Srem & 693 & 2.274 & 54 & 490 & 640 & 1.784 \\
\hline Eastern Srem & 2.259 & 9.882 & 1.545 & 4.756 & 714 & 5.126 \\
\hline Southern Srem & 16.467 & 36.867 & 6.563 & 13.26 & 9.904 & 23.607 \\
\hline VOJVODINA & 120.779 & 373.302 & 60.404 & 165.841 & 60.375 & 207.461 \\
\hline
\end{tabular}


trial culture with its participation of about $45 \%$. If husbandry production areas of the agricultural companies are observed, it can be concluded that the greatest participation is in Southern Srem, Western and Southern Bačka. Finally, there is the region of Northern Srem with the smallest participation. It is noticed that the percentage of soya participation among industrial crops of agricultural households is smaller and that it represents $29.10 \%$. Generaly speaking the presence of soya in the agricultural companies is better and more evident than in the agricultural households in the majority of areas.

Average obtained soya yield - The obtained yield per area unit is an important characteristic of each crop, while the yield level is one of the indexes of production intensity. In the analyzed period (2003-2005) the average yield of soya bean per area unit in Vojvodina was $2.225 \mathrm{~kg}$. The agricultural companies achieve six more in- the agricultural companies is $1.133 \mathrm{~kg} / \mathrm{ha}$, while that difference is smaller in the agricultural households $(655 \mathrm{~kg} / \mathrm{ha})$. Larger yields of soya were obtained in the production areas of Northern Banat and Northern Srem on the agricultural households. The greatest yields were recorded in the region of Southern Srem while the smallest ones were recorded in the region of Middle Banat.

The analysis of achieved production scope per production areas in Vojvodi$n a$ - The production scope represents the production of harvested areas and the obtained yield per area unit. The region of Vojvodina achieves an average annual soya production of $287.868 \mathrm{t}$ in the observed period (table 5). Southern Bačka has about 6o times larger production than Northern Srem and 17 times larger than Northern Banat. Southern and Western Bačka and Southern Srem achieved the greatest soya production. The correlation of achieved der industrial crops), whereas in the agricultural households it is grown on 60.375 ha ( $29 \%$ of areas under industrial crops). Considering the whole agricultural fund of Vojvodina (1.570.584 ha), it is noticed that it is mostly grown in the area of Southern Bačka (17.29 \%) and least grown in the area of Northern Srem (1.23\%). When certain production areas are concerned, average harvested areas under soya vary in the interval 693-37.402 ha. About $70 \%$ of all areas harvested are in the following areas: Southern and Western Bačka, Southern Srem; these are at the same time the areas where soya fields are the most common among all other crops.

The most common appearance of soya among all industrial crops is in the areas of Western (54.48 \%) and Southern Bačka ( $53.29 \%)$, while it is less common in the area of Northern Banat ( $8.38 \%)$. In the period observed, the average yield of soya bean is per area unit is $2.225 \mathrm{~kg} / \mathrm{ha}$. The agricultur-

Table 5 Average achieved scope of soya production ( $t$ ) in Vojvodina for the period 2003-2005.

\begin{tabular}{|c|c|c|c|c|c|c|c|c|c|}
\hline \multirow[b]{2}{*}{$\begin{array}{l}\text { Production } \\
\text { area }\end{array}$} & \multicolumn{3}{|c|}{ Total sum } & \multicolumn{3}{|c|}{ Agricultural companies } & \multicolumn{3}{|c|}{ Agricultural households } \\
\hline & $\begin{array}{c}\text { Average } \\
\text { production } \\
(\mathrm{t})\end{array}$ & $\begin{array}{c}\% \\
\text { participation }\end{array}$ & Rang & $\begin{array}{c}\text { Average } \\
\text { production } \\
\text { (t) }\end{array}$ & $\begin{array}{c}\% \\
\text { participation }\end{array}$ & Rang & $\begin{array}{c}\text { Average } \\
\text { production } \\
(\mathrm{t})\end{array}$ & $\begin{array}{c}\% \\
\text { participation }\end{array}$ & Rang \\
\hline Western Bačka & 76.316 & 26,51 & 2 & 33.97 & 23,98 & 2 & 42.346 & 28,96 & 2 \\
\hline Northern Bačka & 11.22 & 3,90 & 7 & 9.252 & 6,53 & 7 & 1.968 & 1,35 & 7 \\
\hline Southern Bačka & 93.656 & 32,53 & 1 & 36.181 & 25,54 & 1 & 57.475 & 39,30 & 1 \\
\hline Northern Banat & 5.557 & 1,93 & 8 & 4.105 & 2,90 & 8 & 1.452 & 0,99 & 9 \\
\hline Middle Banat & 17.14 & 5,95 & 5 & 13.452 & 9,50 & 5 & 3.687 & 2,52 & 6 \\
\hline Southern Banat & 20.89 & 7,26 & 4 & 16.461 & 11,62 & 4 & 4.428 & 3,03 & 5 \\
\hline Eastern Banat & 15.504 & 5,39 & 6 & 8.623 & 6,09 & 6 & 6.88 & 4,71 & 4 \\
\hline Northern Srem & 1.566 & 0,54 & 10 & 157 & 0,11 & 10 & 1.409 & 0,96 & 10 \\
\hline Eastern Srem & 5.554 & 1,93 & 9 & 4.076 & 2,88 & 9 & 1.478 & 1,01 & 8 \\
\hline Southern Srem & 40.466 & 14,06 & 3 & 15.359 & 10,84 & 3 & 25.108 & 17,17 & 3 \\
\hline VOJVODINA & 287.868 & 100 & & 141.637 & 100 & & 146.231 & 100 & \\
\hline
\end{tabular}

Source: Internal documentation of the Provincial Bureau of Statistics in Novi Sad for the period 2003-2005

dex points of yield $(2.235 \mathrm{~kg} / \mathrm{ha})$ than the agricultural households $(2.108 \mathrm{~kg} / \mathrm{ha})$. The analysis of the obtained yields per certain regions shows that the greatest soya yield was achieved in the region of Southern Banat $(2.529 \mathrm{~kg} / \mathrm{ha})$; especially in the agricultural companies. The smallest yields are recorded on the territory of Northern Banat $(1.636 \mathrm{~kg} / \mathrm{ha})$. The determined values of average yields indicated that areas inside Bačka and Srem have small differences in the obtained soya yields, while the differences are more noticeable in different areas of Banat. The distribution of production areas according to the obtained yield in agricultural companies shows the maximum soya yield in the region of Eastern Srem $(2.664 \mathrm{~kg} / \mathrm{ha})$, while the minimal yield is in the region of Northern Banat $(1.531 \mathrm{~kg} /$ ha). The difference between the maximum and minimum yield of observed areas in production scope of the agricultural companies and agricultural households differs in $4.594 \mathrm{t}$ in favour of agricultural households, which only indicates that the production scope depends more on harvested areas than on the obtained yields. It can be concluded that Southern and Western Bačka and Southern and Northern Srem achieve greater soya production in agricultural households compared to the agricultural companies.

\section{Conclusion}

According to the given analyses, it can be concluded that in the period 2003-2005, the soya in Vojvodina was grown on the average area of 120.779 ha ( $32 \%$ of all areas under industrial crops). In the agricultural companies the soya is grown on the average area of 60.404 ha which represents $13 \%$ of ploughed fields ( $36 \%$ of areas un- al companies achieve $2.235 \mathrm{~kg}$ of soya bean per hectare on average, whereas the agricultural households achieve $108 \mathrm{~kg}$. on average. The greatest yield belongs to Southern Banat, whereas Northern Banat shows the least yields. Considering the fact that the cultivated areas in Southern Banat are smaller compared to Western and Southern Bačka (although the yield is somewhat smaller in these areas), it can be concluded that these two areas are the most important for soya production. About 288.00o $t$ of soya bean is annually manufactured in Vojvodina. A bit less than $60 \%$ of the total production is achieved in the areas of Southern and Western Bačka.

The achieved scope of production is more under the influence of harvested areas than the obtained yield, which results in the fact that the ranking of production areas according to harvested areas and 
production scope is the same. The period to come should gravitate towards the popularization of soya on the agricultural households since soya (especially considering available field capacities) is present in rather small amounts. This especially implies to areas where high yields are achieved but where the presence of soya crops is rather small (the typical example would be the agricultural area of Southern Banat).

\section{References}

Bošnjak, D. 1991. Uticaj nivoa intenzivnosti na rezultate proizvodnje osnovnih ratarskih useva u proizvodnim rejonima Vojvodine, Poljoprivredni fakultet, Institut za ekonomiku poljoprivrede $\mathrm{i}$ sociologiju sela, Novi Sad, pp.1-73.

Bošnjak D., Rodić, V. 2006. Ekonomska obeležja proizvodnje soje, Zbornik ra- dova Instituta za ratarstvo i povrtarstvo 42,110-135.

Đorđević, V., Nenadić, N. 1980. Soja - Privredni značaj, osobine i gajenje, Nolit, Beograd.

Interna dokumentacija Pokrajinskog Zavoda za statistiku u Novom Sadu za period 1976-1995. i period 2000-2005. godina.

Ivanović, B. 1963. Diskriminaciona analiza sa primenom u ekonomskim istraživanjima, Naučna knjiga, Beograd.

Jan, M. 2004. Osvrt na utvrđivanje proizvodnih rejona u Vojvodini, Posebno izdanje serije prirodnih nauka, Sv. 13, Matica Srpska, pp.81-107.

Reljin, S., Jovanović, M., Tica, N. 1997. Soja - ekonomika proizvodnje, Sojaprotein, Bečej.

Rošulj, A. 2006. Osnovna obeležja proizvodnje soje u ratarskim proizvodnim rejonima Vojvodine, Diplomski rad,
Poljoprivredni fakultet, Novi Sad, pp. 1-32.

Stojković, L. 1949. Osnove prirodne biljne rejonizacije Vojvodine, Radovi poljoprivrednih naučnoistraživačkih ustanova, Knjiga 1,.31-53.

Stojković, L. 1972. Proizvodni rejoni Vojvodine - Preštampano iz 'Zemljišta Vojvodine", Institut za poljoprivredna istraživanja Novi Sad, Beograd.

Shurtleff, W., Aoyagi, A. 2004. The History of Soybeans and Soyfoods Around the World - 1100 B.C. to the 1980's, Soyfood Center, Lafayette, California, USA, pp.1-178.

Todorović, J., Kondić, J. 1993. Soja, Banja Luka, pp. 1-158.

Tomić, P., Romelić, J., Lazić, L. 1999. Ekonomska geografija, Institut za geografiju, Prirodno-matematički fakultet, Novi Sad, pp.1-30o. 